\title{
Nasal Chondromesenchymal Hamartoma Masquerading As Malignant Paediatric Tumour
}

\section{Malign Pediyatrik Tümör Gibi Prezante Olan Nazal Kondromezenkimal Hamartom}

\section{Sui Teng TAN $\odot$, Saraiza Binti ABU BAKAR $\oplus$, Abdul Fattah ABDULWAHAB $\odot$, Khadijah Mohd NOR $\odot$}

Ethics Committee Aproval: Not Applicable.

Confillict of Interest: The authors declare that they have no conflict of interest.

Funding: None.

Informed Concent: Informed consent was taken.
Cite as: Tan ST, Abu Bakar SB, Abdul Wahab AF, Nor KM. Nasal Chondromesenchymal Hamartoma Masquerading As Malignant Paediatric Tumour. Medeniyet Med J. 2019;34:223-8

\begin{abstract}
Nasal Chondromesenchymal Hamartoma (NCMH) is a rare, benign tumour of sinonasal tract usually seen in infants. Even though it is benign in origin, its aggressive clinical behaviour and florid radiological finding always mislead the initial diagnosis, mimicking a malignant sinonasal tumour.

We report a case of NCMH in a 2-year-old boy who was referred by an ophthalmologist for progressive facial distortion, left eye proptosis, persistent left rhinorrhoea and epiphora. Biopsy obtained from the nasal cavity which appeared to be lobulated mass on endoscopic examination confirmed that it was Nasal Chondromesenchymal Hamartoma (NCMH). Surgical excision of the tumour was performed. The symptoms of NCMH depend on the tumour location, thus the clinical presentation can be varied. The only way to establish the diagnosis of NCMH is by histopathological and immunohistochemical examination of the tumour. Complete surgical treatment is advocated once the diagnosis is confirmed. This benign tumour has an established relation with the DICER1 mutations, hence other DICER1 tumours need to be ruled out at the time of diagnosis.
\end{abstract}

Keywords: paediatric nasal mass, hamartoma, chondromesenchymal hamartoma, DICER 1 mutation

öz

Nazal Kondromezenşimal Hamartom (NKMH), sinonazal traktusun genellikle infantlarda görülen nadir benign bir tümörüdür. Köken olarak benign olsa da, agresif klinik davranıșı ve florid ile görüntüleme bulguları malign bir sinonazal tümörü taklit ederek her zaman ilk tanıda yanlıss yönlendirmeye neden olmaktadır. Bu yazıda ilerleyici fasiyal distorsiyon, sol gözde proptozis, sol taraflı persistan rinore ve epifora ile bir oftalmolog tarafindan yönlendirilen 2 yaşındaki bir erkek hastadaki bir NKMH vakasını sunmaktayız. Nazal kaviteden, endoskopik muayenede lobüle kitle görünümünden alınan biyopsi bunun Nazal Kondromezenşimal Hamartom (NKMH) olduğunu doğrulamıştır. Tümör cerrahi olarak çıkarılmıştır. NKMH'nin semptomları tümörün yerine bağlı olduğundan klinik prezentasyon değişkenlik gösterebilmektedir. NKMH tanısını koymada tek yol tümörün histopatolojisi ve immünohistokimyasıdır. Tanı doğrulandıktan sonra tam bir cerrahi tedavi yapılması savunulmaktadır. Bu benign tümörün DICER1 mutasyonları ile bilinen bir ilişkisi mevcuttur, bu nedenle diğer DICER1 tümörlerinin tanı anında dışlanması gerekmektedir.

Anahtar kelimeler: pediatrik nazal kitle, hamartom, kondromezenşimal hamartom, DICER1 mutasyonu
Received: 09.11.2018

Accepted: 17.12 .2018

Online First: 10.06 .2019

Corresponding Author: K.M. Nor

ORCID: 0000-0001-6406-0553 Universiti Putra Malaysia Faculty of Medicine and Health Sciences, Ear Nose and Throat Unit, Department of Surgery, Malaysia

kay24434@gmail.com

S.T. Tan ORCID: 0000-0002-0720-9208 S.B. Abu Bakar ORCID: 0000-0003-0247-4616 Serdang Hospital, Department of Otorhinolaryngology, Head and Neck Surgery, Selangor, Malaysia

A.F. Abdulwahab ORCID: 0000-0003-4912-8980 Ara Damansara Medical Center, Department of Otorhinolaryngology, Head and Neck Surgery, Selangor, Malaysia 


\section{INTRODUCTION}

Nasal masses in infancy are uncommonly encountered compared with the adult population. Most of the tumours in paediatric patients are developmental anomalies, such as, encephalocoele, glioma and nasolacrimal duct cyst ${ }^{1}$. However, a variety of benign and malignant soft tissue tumours can occur in infancy as well ${ }^{2}$. Majority of the head and neck tumours in childhood are benign in nature, as opposed to the malignant tumours of this region which are uncommon and accounts for around 5\% of neoplasms. Childhood neoplasms are more frequently reticuloendothelial, neural or mesenchymal in origin whereas epithelial neoplasms are predilected in adulthood ${ }^{3}$. We present a case of nasal chondromesenchymal hamartoma (NCMH) which was initially confused with malignant tumour due to its aggressive behaviour. Its clinical rarity made the clinicopathology entity remarkable with diagnostic challenge and implication in the management.

\section{CASE REPORT}

A 2-year-old full-term boy was referred to us by the ophthalmology department for the left nasoorbital swelling persisting for the past two months. The swelling was not evident during delivery until two months previously. It started as a pea-sized swelling and was progressively increasing in size with facial deformity, associated with persistent epiphora over the left eye and rhinorrhea bilaterally.

On examination, there was a swelling over the left naso-orbito region with proptosis of the left eye and widening of the nasal bridge (Fig. 1). Nasal bone was crooked and nasal septum was deviated due to the compression effect of the swelling. Otherwise, he was thriving well and his vision was normal as per ophthalmologist's assessment.

Computed Tomography (CT) scan of the brain, orbit and paranasal sinuses showed an expansile heterogeneously enhancing mass occupying left nasal cavity with dystrophic calcification measuring $3.5 \times 2.7 \times 3.0 \mathrm{~cm}$, extended inferiorly to the left ethmoidal sinus, posteriorly to the posterior choana, medially bounded by nasal septum and laterally involving the left maxillary sinus. There was evidence of bony destruction of the adjacent structures such as superior alveolar process of the maxilla, left maxillary sinus and left ethmoidal sinus. Magnetic Resonance Imaging (MRI) of

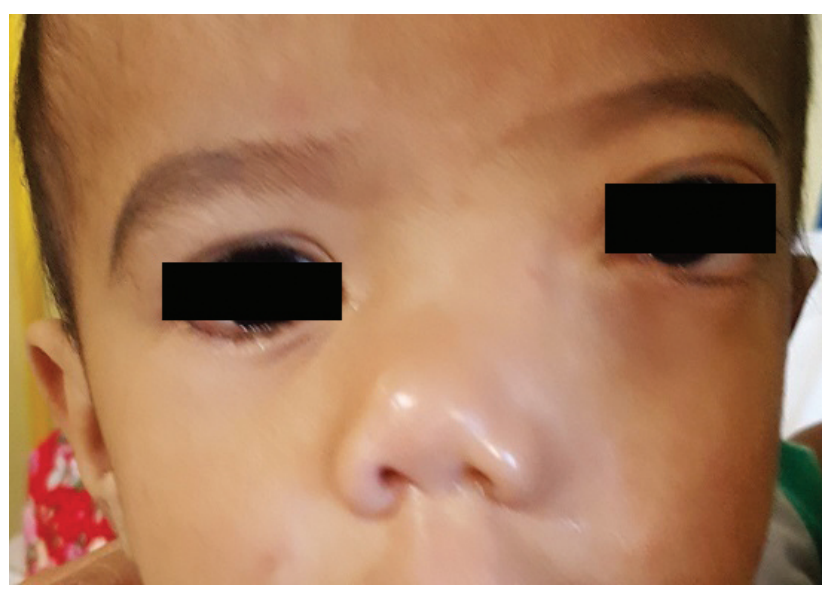

Figure 1. There is proptosis on the left eye, widening of the nasal bridge and crooked nasal bridge secondary to soft tissue mass distension in left nasal cavity and paranasal sinuses.

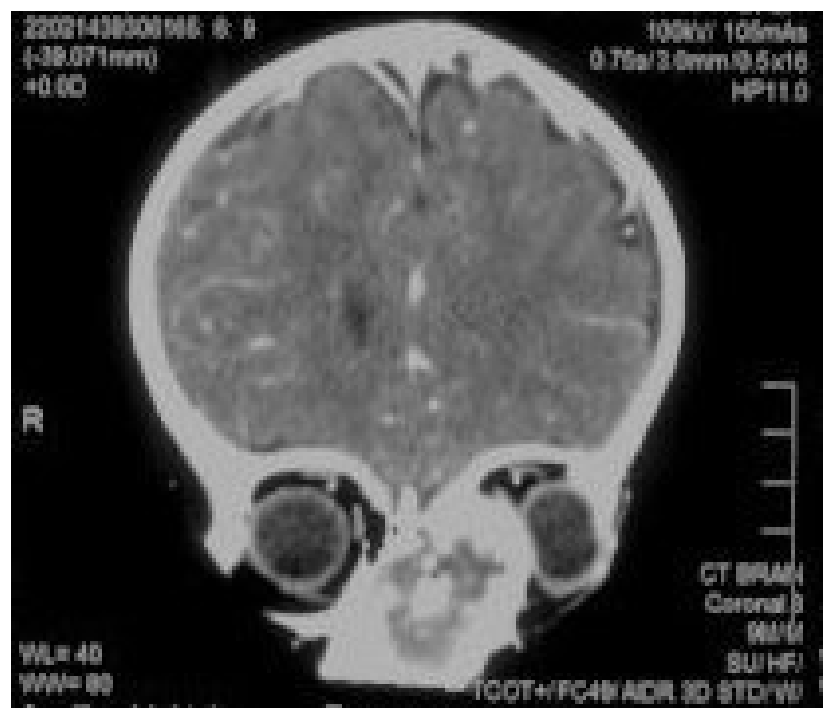

Figure 2. CT scan of brain, orbit and paranasal sinuses showed an expansile heterogeneously enhancing mass occupying left nasal cavity with dystrophic calcification extends to the left ethmoidal sinus causing displacement of the left eye globe. 


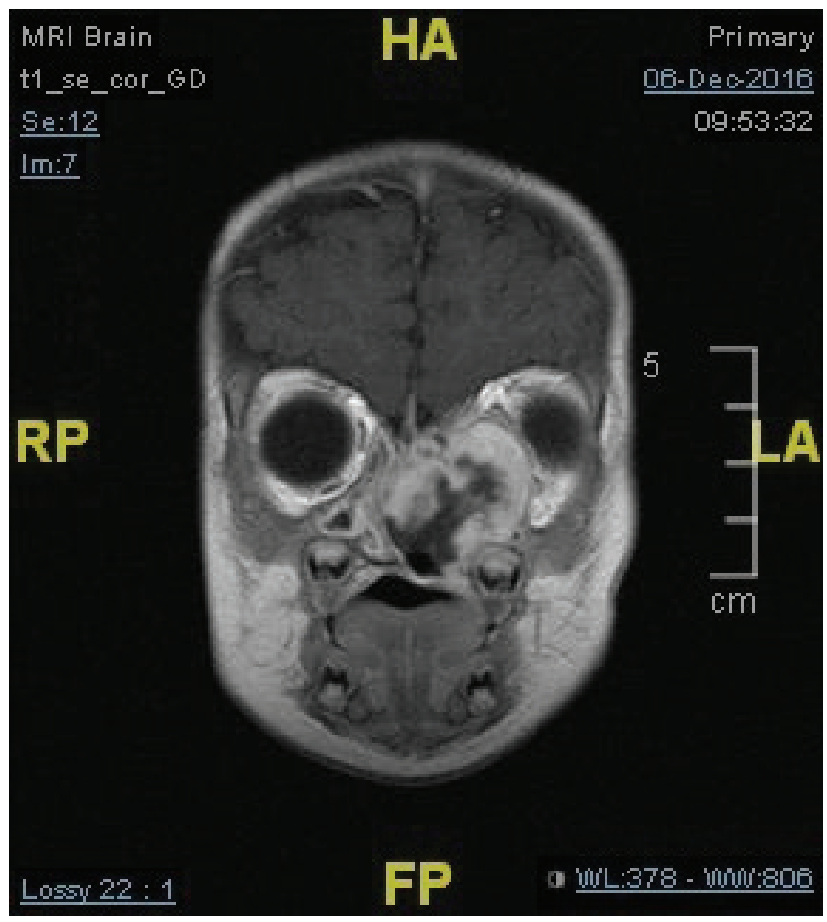

Figure 3A. MRI of brain and paranasal sinuses in coronal view (3A) and axial view (3B) showed there was a clear fat plane between the intranasal mass with the left medial rectus muscle. No evidence of intracranial extension.

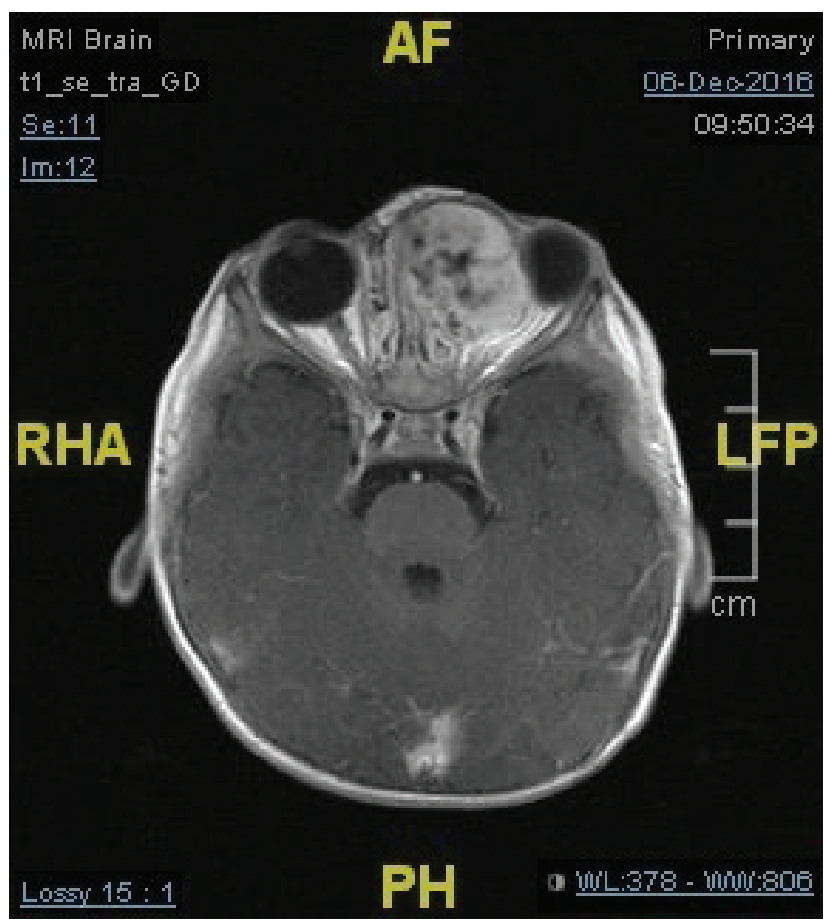

Figure 3B. MRI of brain and paranasal sinuses in coronal wiew (3A) and axial view (3B) showed there was a clear fat plane between the intranasal mass with the left medial rectus muscle. No evidence of intracranial extension.

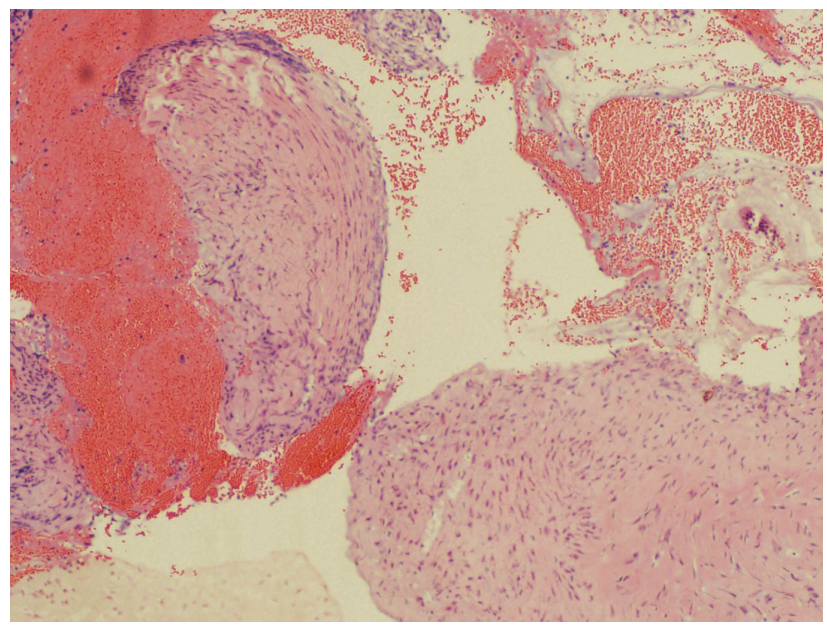

Figure 4A. This micrograph illustrates nodules of cartilage in varying sizes, shapes and contours focally lined by respiratory type of epithelium and transitional epithelium (H\&E staining,x 10).

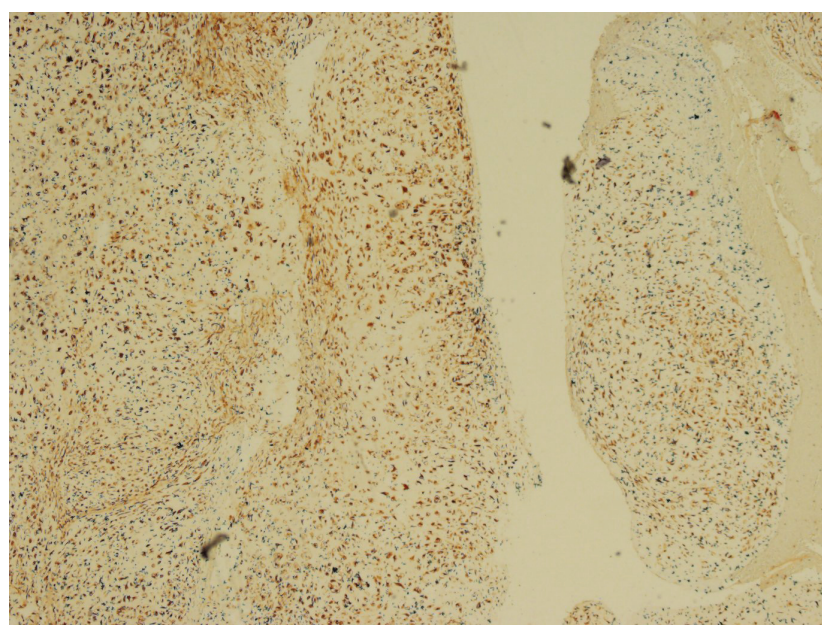

Figure 4B. This micrograh shows the cartilaginous noduse are immunoreactive for $\mathrm{S}-100$ protein $(\mathbf{x} 10)$.

the brain and paranasal sinuses confirmed that the epicentre of the mass was extraconal in origin with clear plane between the mass and the left medial rectus muscle. There was no intracranial extension.

Examination under anaesthesia and biopsy of the lesion were done prior to the definitive treatment. The histopathological examination of the soft tissue biopsy was consistent with the diagnosis of nasal chondromesenchymal hamartoma. Positive immunohistochemical stain S-100 further confirmed the diagnosis of $\mathrm{NCMH}$. 
He was then brought to the operating theatre for endoscopic excision of the tumour. Intraoperatively, there was an extensive whitish well encapsulated fibrous soft tissue mass in the left nostril which extended to the base of the skull and laterally extended into the left maxillary sinus causing middle meatal auto-antrostomy. On the floor of the orbit was dehiscence of lamina papyracea was observed. Left periorbital region was intact. We managed to excise almost $90 \%$ of the tumour, leaving part of the residual tumour at the base of the skull which was technically challenged.

Postoperatively, he was well with no complication arising from the endoscopic sinus surgery. Subsequent nasoendoscopies during regular outpatient visits up to 1 year postoperatively did not show any tumour recurrence.

\section{DISCUSSION}

Hamartoma is defined as excessive focal overgrowth of naturally occurring cells and tissues which does not produce the normal architecture of the surrounding tissue even though the cellular elements are mature and identical to those found in the remainder of the organ ${ }^{1,4}$. It can be classified into epithelial, mesenchymal, and mixed types. NCMH has a mixed morphological structure comprising predominantly mesenchymal and cartilaginous components ${ }^{4,5}$.

Mcdermott et al. ${ }^{6}$ was the first to recognise $\mathrm{NCMH}$ as a distinct disease entity in 1998 whereby they described a series of seven patients with a tumefactive process in the nasal cavity entending into paranasal sinuses and intracranial involvement ${ }^{4,5}$. According to the systemic review conducted by Mason et al. ${ }^{7}$, vast majority of the cases that had been reported were predominantly involving the infants below 1 -year-old, however, there had been up to seven cases which involved adult with the highest age of $69^{7}$. Although it is a benign lesion, a case of malignant transformation was reported by Li et al. ${ }^{8}$ in 2013.
The presentation of the NCMH depends on its location and the size of the hamartoma ${ }^{4}$. Typically, $\mathrm{NCMH}$ presents with nasal obstruction, rhinorrhea, facial deformity and ophthalmic signs, which indicate the involvement of the NCMH along the nasal cavity,paranasal sinuses and around the orbits ${ }^{4,7}$. Ophthalmic signs include proptosis, strabismus and hypertelorism mainly due to the compression effect of the intranasal mass causing displacement of the eye globe $e^{4,7,9}$. Occasionally, patients may have intraoral symptoms due to the involvement of the oral cavity ${ }^{7}$. Symptoms and signs of $\mathrm{NCMH}$ can be varied, and patient may present to the Ophthalmology or Oral Surgery clinics during their first visit instead of the Otorhinolaryngology (ORL) clinic. It is essential for the doctors in these specialties to bear in mind that NCMH should be considered in the differential diagnosis ${ }^{7}$. Our patient was first referred by his primary care doctor to the Ophthalmology clinic in view of proptosis and progressive swelling over the left naso-orbital region without nasal symptom. This clearly explained the initial symptoms were mainly based on the location of the NCMH, in which the growth epicentre was found over the left ethmoidal region causing proptosis of the left eye.

Tumours of head and neck region in paediatric patients are very rare and mostly are benign in nature, however, making the correct diagnosis based on the clinical and radiological assessment will be very challenging ${ }^{5}$. NCMH can be easily misdiagnosed as a malignant tumour clinically in view of its aggressive, fast growing and destructive characteristics involving surrounding structure. Preoperative imaging prior to any surgical procedure provides a valuable assessment regarding the extension of the mass and involvement of the surrounding structures such as paranasal sinuses, orbit and brain ${ }^{7}$. NCMHs are seen to CT scan in delineation of soft tissue and invasion to the surrounding structures in comparison to the CT scan ${ }^{7}$. For our patient, CT scan and MRI showed expansile mass heterogeneously enhanced within nasal cavity with epicentre at the left anterior ethmoidal sinus 
superiorly and the floor inferiorly. The compression by the mass caused lateral displacement of the left globe, left rectus muscle and left optic nerve. Considering the progressive clinical symptoms and radiological findings, a benign lesion such as $\mathrm{NCMH}$ also mimicks malignant tumours, namely chondrosarcoma, rhabdomyosarcoma and chordoma $^{1,7}$.

Diagnosis of NCMH can only be ascertained by obtaining the tissue biopsy and positive immunohistochemical staining. Typically, NCMHs are composed of proliferation of mature or immature cartilaginous and mesenchymal elements. There are large lobules of cartilage with sharp interface with the surrounding stroma ${ }^{1,10}$. However, these morphologies may overlap with those of other malignant chondroid lesions such as chondrosarcoma and chordoma. Even though the histological examination result of the tissue biopsy material of our patient was consistent with the finding of NCMH as described before, further testing for S100, SMA and cytokeratin stains had been carried out. Generally, cytokeratin stains will be positive for chordoma and negative for $\mathrm{NCMH}^{1,4,10}$. Immunohistochemical stains in our patient's biopsied tissue showed positivity for S100 and SMA, and negativity for cytokeratin which further confirmed the diagnosis of NCMH.

Early presentation of most of the NCMH cases in the infancy suggested its genetic predisposition. Priest et al. ${ }^{11}$ and Stewart et al. ${ }^{12}$ investigated patients with both NCMHs and pleuropulmonary blastoma whereby their recent findings established genetic evidence of the association between NCMH tumour, and DICER1 mutation . Therefore, ultrasound of the urinary system was done for our patient to rule out cystic nephroma, which is one of the disease entities in DICER1 tumour spectrum. Surgeons and physicians should be aware of this association when patient presents with sinonasal tumour or orbital signs in order to holistically manage the patient.
$\mathrm{NCMH}$ can be easily misdiagnosed as other malignant tumours when taking all these diagnostic challenges into consideration. Patient may end up with unnecessary radical surgical excision or chemoradiotherapy if a wrong diagnosis is made. $\mathrm{NCMH}$ carries benign biological behaviour so complete surgical excision a sufficient therapy and important in preventing recurrence ${ }^{5,7}$. However complete surgical excision is not technically feasible in all cases due to the extension of the mass. In their systemic review Mason et al reported nine patients with disease recurrence ${ }^{7}$, most likely due to incomplete excision. Preoperative radiological assessment and approach of the surgery were planned for this patient to ensure complete excision of the mass. The patient was followed up in the ORL clinic up to 1 -year postoperatively without any signs of recurrence.

\section{CONCLUSION}

In a nutshell, making an accurate diagnosis in paediatric patients presented with nasal obstruction caused by tumour or tumour-like non-neoplastic malformation can be very challenging. The presentation of NCMH depends on its location, with nasal obstruction, nasal mass and ophthalmic signs being the most common problems. Histopathological examination and ancillary studies are the mainstays of diagnostic pocess. Complete surgical excision is the definitive treatment which reduces recurrence. This case report highlights the fact that NCMH can masquerade some other malignant tumours due to their aggressive clinical and radiological aspects, and surgeons should be vigilant in making the diagnosis and associated disease spectrum in order to avoid unnecessary and harmful treatment of the patient.

\section{REFERENCES}

1. Ruth SE, Mario $\mathrm{AMZ}$, Ramon ABL. Congenital nasal chondromesenchymal hamartoma. Philipine J Otolaryngol Head Neck Surg. 2009;24:23-6. [CrossRef]

2. Thawley SE, Panje WR, Batsakis JG, Lindberg RD. Comprehensive management of head and neck tumors. $2^{\text {nd }}$ edition. Philadelphia: WB Saunders Company; 1999. p. 
1843-44, 1876-78.

3. Cummings CW, Flint PW, Haughey BH, Harker LA, et al. Otolaryngology Head and Neck Surgery. $3^{\text {rd }}$ ed. St. Louis, Missouri: Mosby Year Book; 1998 p.1212, 3988, 418385.

4. Eloy Ph, Trigaux H, Nassogne MC, Weynand B, et al. Case report: Nasal chondromesenchymal hamartoma. Int J Pediatr Otorhinolaryngol Extra. 2011;6:300-3. [CrossRef]

5. Alrawi M, McDermott M, Orr D, Russell J. Nasal chondromesenchymal hamartoma presenting in an adolescent. Int J Pediatr Otorhinolaryngol. 2003;67:669-72. [CrossRef]

6. McDermott MB, Ponder TB, Dehner LP. Nasal chondromesenchymal hamartoma: an upper respiratory tract analogue of the chest wall mesenchymal hamartoma. Am J Surg Pathol. 1998;22:425-33. [CrossRef]

7. Katrina AM, Annakan N, Evgenia T, Perumal GC. Nasal chondromesenchymal hamartoma: A systematic review of the literature with a new case report. J Otolaryngol Head Neck Surg. 2015;44:28 [CrossRef]
8. Li Y, Yang QX, Tian XT, Li B, Li Z. Malignant transformation of nasal chondromesenchymal hamartoma in adult: a case report and review of the literature. Histol Histopathol. 2013;28:337-44.

9. Avci H, Comoglu S, Ozturk E, Bilgic B, Kiyak OE. Nasal chondromesenchymal hamartoma: A rare nasal benign tumour.Kulak Burun Bogaz Ihtis Derg. 2016;26:300-3. [CrossRef]

10. Unal A, Kum RO, Avci Y, Unal DT. Nasal chondromesenchymal hamartom, a rare pediatric tumor: Case report. Turkish J Pediatr. 2016;58:208-11. [CrossRef]

11. Stewart DR, Messinger Y, Williams GM, Yang J, et al. Nasal somatic mutations of DICER1 in the pleuropulmonary blastoma tumor predisposition disorder. Hum Genet. 2014;133:1443-50. [CrossRef]

12. Priest JR, Williams GM, Mize WA, Dehner LP, McDermott $M B$. Nasal chondromesenchymal hamartoma in children with pleuropulmonary blastoma-A report from the International Pleuropulmonary Blastoma Registry. Int J Pediatr Otorhinolaryngol. 2010;74:1240-4. [CrossRef] 